\title{
GEOMORPHOLOGICAL PROCESSES ON TERRESTRIAL PLANETARY SURFACES
}

\author{
Robert P. Sharp \\ Division of Geological and Planetary Sciences, California Institute of Technology, \\ Pasadena, California 91125
}

\section{INTRODUCTION}

This review deals with features and processes on planetary surfaces, first by examining the impact of photographic explorations of Moon, Mars, and Mercury on studies of surface processes on our own planet, and second by treating matters related to current deformation of Earth's surface.

An unanticipated outfall from the space program has been a strong upsurge of interest in Earth-surface processes. This occurs because understanding and interpretation of features on other planetary surfaces is most effectively approached through analogues from Earth (Belcher et al 1971, Frey 1979, Hartmann 1974, Komar 1979, Malin 1974, 1977, Trevena \& Picard 1978, Veverka \& Liang 1975, as examples among others). Geologists and geomorphologists (students of landforms and surface processes) are able to make significant contributions to space exploration programs because of their background and experience with earthly forms and processes.

Planetary exploration has proved to be a two-way street. It not only created interest in Earth-surface processes and features as analogues, it also caused terrestrial geologists to look on Earth for features and relationships better displayed on other planetary surfaces. Impact cratering, so extensive on Moon, Mercury, and Mars, is a well-known example (Roddy et al 1978). Another is the huge size of features such as great landslides and widespread evidence of large-scale subsidence and collapse on Mars, which suggest that our thinking about features on Earth may have been too small scaled. One of the lessons from space is to "think big." 
With some exceptions (Cotton 1944), volcanologists have been more concerned with mechanisms of eruption and with petrology (chemistry and physical characteristics) than with the morphological features created by volcanism. However, volcanic landforms are now receiving much greater attention because of exploration of Moon and Mars.

The space program has also generated a high level of interest in such phenomena as catastrophic floods, erosional and depositional work of the wind, mass movements (landslides, earthflows, creep), perennially frozen ground, ground ice, sapping processes, and large-scale crustal collapse. Planetologists, who perhaps once thought that permafrost was a type of commercial refrigerator, now use the word freely and confidently, although sometimes too loosely.

On Earth, the work of wind and of mass movements is so overshadowed by erosional and depositional products of water that the effects are hard to evaluate. Opportunity to observe the products of wind and mass movements on other planetary surfaces, particularly on Mars where they now dominate, brings a fuller appreciation of their relative effectiveness on Earth.

Surface features on other planets are largely fossil, affording a record of events and conditions extending back three to four billion years. Many earthly features are also fossil, but of more modest antiquity, a few million years at most. This is so because vigorous terrestrial weathering, erosion, and deposition quickly modify, erase, or bury antecedent forms and the records of past events. Exploration of other planetary surfaces provides opportunity to identify and evaluate features, processes, and conditions that may have been important on Earth at some earlier time but are unappreciated owing to the loss of record.

The problem of distinguishing impact craters from volcanic craters, the morphology of lava-flow complexes, the surface manifestations of ejecta blankets and tephra sheets (fragmental volcanic material), the products of eolian erosion, the creation of channels by processes other than fluvial erosion, the possibilities of ground-ice deterioration on a scale far surpassing anything seen on Earth, the creation of landscapes and landforms by sapping mechanisms, and the role of collapse in creating chaotic terrains, huge chasms, and complex networks of smaller chasms are all matters receiving attention owing to space exploration.

Recently, interest in surface features and processes on Earth has been further stimulated by desire for protection from natural hazards, such as earthquakes, floods, and landslides. Increased concern with soils, alluvium (stream deposits), colluvium (slope mantles), and other Holocene (the last 11,000 years) deposits mantling the earth is demonstrated by formation of the Society for Quaternary Geology (the geology of the last 2-3 million years), establishment of a Journal of Quaternary 
Research, creation of Quaternary Research institutes, and an outflow of books and professional articles. New geological engineering companies dealing principally with surface problems have sprung up, and older firms have expanded rapidly in size, geographical distribution, and scope. Environmental impact statements for large projects, such as the Alaska pipeline or the liquid natural gas terminal on the Pacific Coast, demand a wide spectrum of talents and interests. Kirk Bryan used to say, with a twinkle in his eye, that a geomorphologist's (also read Quaternary geologist's) best assets were a strong back and a shovel. They have both now been replaced by the backhoe and bulldozer.

Concern with surface forms and processes on Earth affecting human activities directs attention to small-scale landforms (micro-morphology) in their relationship to fault activity and slope stability. Attention is also focused on micro-stratigraphy (history and layering) of surficial materials for the same purposes. Micro-stratigraphic studies are providing information on the recurrence interval of earthquakes of specified magnitude along faults of known historical activity. This is a method of earthquake forecasting, crude and approximate to be sure, but one that represents a solid approach to the subject.

Micro-stratigraphy and micro-morphology are both dependent upon micro-chronology, the determination of relatively short intervals of geological time. Radioactive, chemical, paleomagnetic, and tephrachronological methods are all making contributions on this score. Determination of rates at which geological processes proceed and geological changes occur is a goal toward which progress is being made on both the relative and absolute fronts, albeit slowly.

Had this paper been prepared a decade ago, almost surely the prime focus would have been upon fluvial processes, then so vigorously pursued under stimulation of a group centered in the Water Supply Division of the US Geological Survey. The subject of fluvial processes is downplayed here simply because the results of that work have now become well known and are widely integrated into the professional literature. Anyone wishing to get a feel for the pertinence and impact of modern hydrological research should read the second chapter in Compton's (1977, pp. 19-46) physical geology book. Not only is this a fine example of pedogogy, it also nicely digests some fruits of that research.

\section{FORMS AND PROCESSES ON OTHER PLANETARY SURFACES}

\section{Volcanic Features}

Volcanology, always a fascinating subject in its own right, has received greatly increased attention owing to the space program, initially because 


\section{SHARP}

of the similarity between impact and volcanic craters (Piero 1976, Roddy et al 1978), especially those created by gas-rich explosions, and subsequently because of the variety of volcanic features identified on other planetary surfaces. Planetological interest in volcanology is attested by conferences, field trips, and guidebooks, supported by the National Aeronautics and Space Agency (Greeley 1974, Greeley \& King 1977).

Much attention has been given to large shield volcanos of the Hawaiian type (Macdonald \& Abbott 1970) and to the associated caldera, because of the impressive development of similar features in the Tharsis region of Mars (Carr 1973, 1974b, Carr et al 1977b). A shield volcano is a cone of gentle slope $\left(5^{\circ}-15^{\circ}\right)$ and usually of large size, formed primarily by extrusions of fluid lavas from a central vent or flank fissures. A caldera is a large flat-floored depression formed in part by collapse at the summit of such cones. The need to distinguish shield volcanos from other volcanic constructs, as viewed from an orbiting spacecraft at distances in excess of $1000 \mathrm{~km}$, has caused volcanologists and planetary scientists to look more carefully at the pattern of forms created on the flanks of these cones by successive outpourings of lava. Volcanologists are familiar with lava channels, lobate tongues, flow units, lava levees, fissure eruptions, and similar features but have perhaps not fully appreciated the strongly lineated pattern of these forms when viewed from very high altitudes. The size of martian shields, especially Olympus Mons, roughly five times larger than any corresponding feature on Earth, has astounded terrestrial geologists. Smaller volcanic forms are also of interest (Greeley 1973, Malin 1977).

Distinguishing sheets of debris thrown out of an impact crater from sheets or lobes of material extruded from central volcanic vents, one means of differentiating impact from volcanic craters, has focused attention on the detailed morphology and characteristics of lava accumulations and pyroclastic deposits. Pyroclastics include all fragmental material ejected by volcanic explosions. Planetologists may not have appreciated fully the scale and mobility of such deposits or their possible role in creating landforms. On Earth, sheets of firmly welded pyroclastics form great, level, ponded areas within regions of otherwise rugged relief. Mackin's (1969, pp. 743-46) posthumous paper addressed to the possibility of pyroclastic materials on the lunar surface, based on wide experience with such rocks in southwestern Utah and southeastern Nevada, deserves more attention. Considerable thicknesses of pyroclastic debris can be emplaced over large areas by flow, and a thinner blanket is even more widely distributed by air fall. The mantling of topographic relief, possibly by pyroclastic materials, is recognized on Mars (West 1974, Malin 1979), but more attention could and should be given to the 
unusual forms created when such a blanket is partly removed by erosion.

Among the striking features of the lunar surface are narrow, deep, steep-walled, usually winding chasms, known as rilles, that start and stop abruptly. The abundance of volcanic rock on the lunar surface causes one to seek for an explanation of rilles in some type of volcanic process. This directed attention to tunnels and tubes within earthly lava flows, heretofore of interest as tourist attractions and for harboring perennial deposits of ice. Collapse of the roofs of such features has created small-scale forms resembling lunar rilles. Greeley $(1970,1971 \mathrm{a}, \mathrm{b})$ and Greeley \& Hyde (1972) have been particularly active in this investigation, having at the same time increased understanding of the function of lava tubes within streams of flowing lava. This is a matter of considerable concern in areas of current volcanic activity, Hawaii for example.

The number, nature, size, and variety of channels on the martian surface go far beyond the category of lunar rilles and raise perplexing questions of origin (Milton 1973, Sharp \& Malin 1975, Masursky et al 1977). Again, because of abundant martian volcanic features, consideration has been given to volcanic mechanisms of channel formation. Erosion by ash flows and glowing avalanches has long been posited, but such erosion appears limited to a narrow zone peripheral to the source of such ejections, usually a central vent. Erosion by flowing lava was hypothesized by Carr (1974a), but it seems capable of creating only small channels. Nonetheless, concern over the origin of martian channels has caused terrestrial volcanologists to look with a more critical eye at lava channels on Earth. Some lava channels on volcanic cones are the product of accretion rather than erosion. This occurs because the lateral margins of a narrow lobate lava tongue congeal while the central part flows away leaving a channel confined by natural levees of congealed rock.

Isolated, round-topped, steep-sided hills on the surface of Moon, Mars, and Mercury are something of an enigma. On Earth, similar features are commonly erosion residuals created by an episode of tectonic uplift followed by extensive subaerial erosion. This explanation cannot easily be invoked for many parts of other planetary surfaces where tectonic activity and erosion are minimal, so attention again shifts to volcanism and particularly to tholoids. A tholoid is a mass of highly viscous lava, often glassy, which has been extruded from a central vent, like mastic squeezed from a tube. Being too stiff to run away as a lava flow, it simply accumulates as a mound. Tholoids tend to be dome shaped, but many variations are recognized on Earth (Williams 1932, Macdonald 1972). Their possible abundance on other planetary surfaces, with characteristics largely unmodified by secondary processes, invites study. Volcanology can help immensely in understanding features and processes 


\section{SHARP}

on other planetary surfaces, and volcanologists in turn have opportunity to inspect features created by volcanism where it is not so severely contested by tectonism and erosion as on Earth.

\section{Eolian Erosion}

Terrestrial geologists and engineers have not ignored eolian processes on Earth, but generally more attention has been given to depositional than to erosional products (Blackwelder 1931). However, interest in eolian erosion has been greatly increased by discovery of features on Mars possibly created by wind erosion (Figure 1). Expressions of this interest take the form of NASA support of a field conference on eolian processes (Greeley et al 1978), and laboratory investigations simulating martian features and conditions (Greeley et al 1974a,b, Iversen et al 1976, Wood et al 1974).

Wind is one of the few exogenic processes judged to be currently effective on the surface of Mars (Gifford 1964, Ryan 1964, Loomis 1965, Sagan \& Pollack 1969, among others), and an assumption that it has long been a major agent shaping martian features seems justified. Evidence for both eolian deposition (Sagan et al 1971, Cutts \& Smith 1973) and erosion (Arvidson 1972, McCauley 1973, Sagan 1973, Cutts 1973, Veverka 1975, Arvidson et al 1976) is advanced from study of orbiter photos. These processes were early hypothesized by McLaughlin (1954a, b, 1956), and the modern view is summarized by Mutch et al (1976, pp. 235-61).

On Earth, geological work by wind is hampered by vegetation, and the results of eolian erosion, even when it occurs, are usually rapidly modified or obscured by fluvial processes. The opportunity to study and evaluate the largely unmodified products of martian eolian erosion, continuing relatively uncontested for long intervals of time, has caused geologists to search more extensively and critically for features of eolian erosion on Earth, with profitable results.

Leaders in this effort have been J. F. McCauley and associates (1977) of the Astrogeology Branch of the US Geological Survey. Their attention has focused largely upon a feature long recognized as a product of eolian erosion, the yardang (Blackwelder 1934, p. 159). A yardang is an elongate streamlined ridge resembling an inverted ship's hull. Although usually of dimensions measurable in meters, some yardangs are up to $60 \mathrm{~m}$ high and a few are $2 \mathrm{~km}$ long and $1 \mathrm{~km}$ wide (McCauley et al 1977, p. 26, 50). Yardangs are recognized in the desert areas of Central China, Iran, Afghanistan, the Arabian Peninsula, Africa (Egypt, Libya, Sahara, Chad, and Namib), Peru, and North America. Although they occupy only a miniscule part of the terrestrial surface and require conditions of 
Annual Reviews

R www.annualreviews.org/aronline

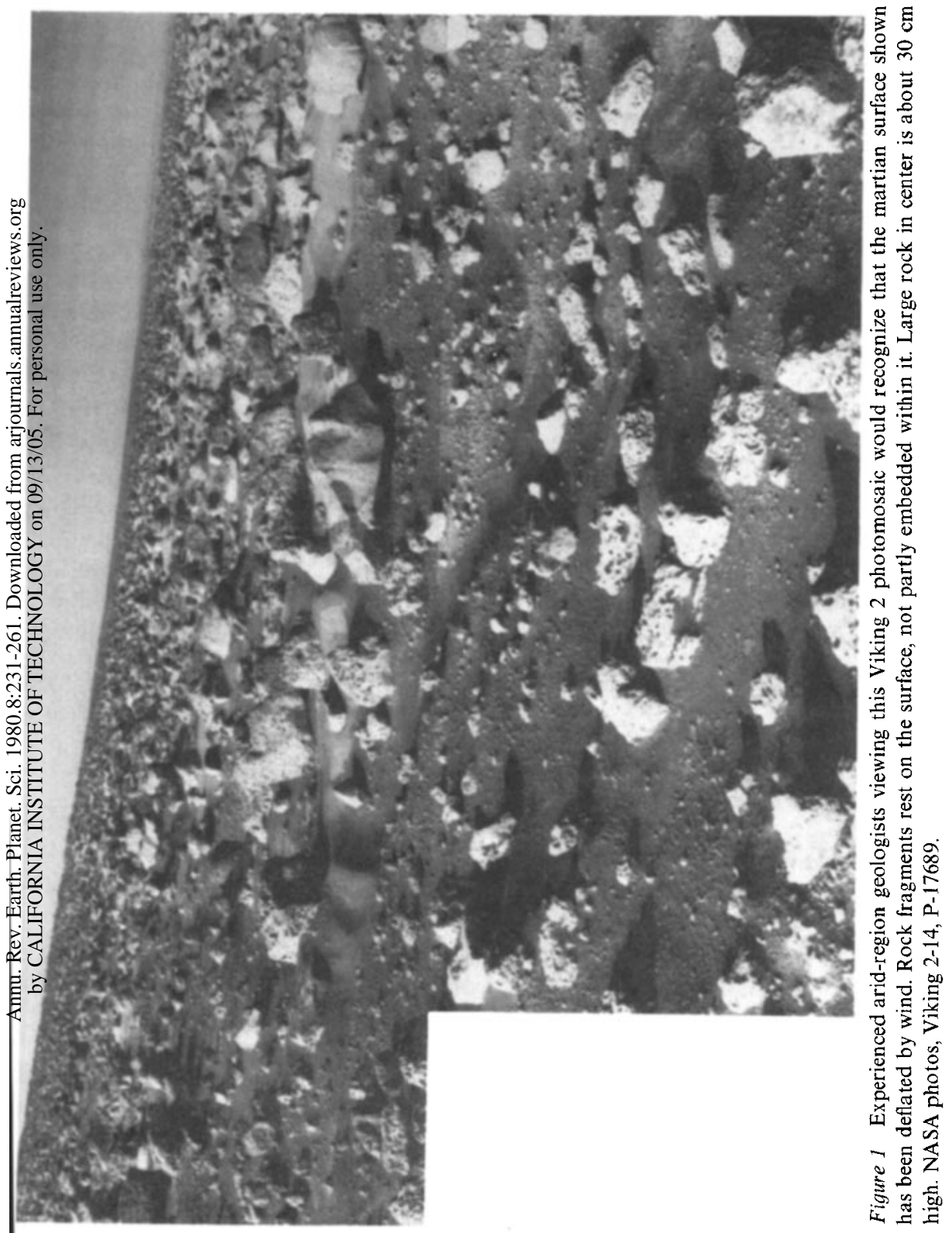




\section{$238 \quad$ SHARP}

high aridity, near-unidirectional winds, favorable material, and some assistance from weathering to form, the existence of yardangs in greater number and larger size in more areas than heretofore appreciated is significant. The McCauley group (1977, p. 169) feels that yardangs are more the product of deflation (removal of loosened material) than of abrasion (mechanical wear of coherent material). The erosional work of wind on Earth may have been greater than generally realized, although the magnitude of eolian erosion has long been a matter of debate (Ball 1927, Blackwelder 1931, Hobbs 1917, Keyes 1912, Tolman 1909).

\section{Ground Ice and Permafrost}

Prior to World War II, geologists in the United States, with some exceptions (Leffingwell 1919, Taber 1943, among others), had limited experience with perennially frozen ground compared to scientists in Canada and northern Eurasia, particularly Russia. Military operations during World War II required engineering treatment of frozen ground and ground ice and stimulated investigations and interest on the part of both geologists (Muller 1947) and engineers, which continued with strength into the post-war era. Large-scale operations such as the oil fields and pipelines of Alaska, and environmental considerations relating to them, have made extensive use of this experience and knowledge. The United States can now claim significant contributions and competent workers in the field (Anderson et al 1972, 1973, Black 1976, Corte 1969, Lachenbruch 1962, Péwé 1969, Stearns 1966, Washburn 1973, among many others). The exploration of Mars has created interest in this subdiscipline on the part of a wholly new clientele, the planetary scientists (Mutch et al 1976, Carr \& Schaber 1977).

Permafrost is simply a condition of ground perennially at a sub-zero temperature. It may or may not be accompanied by ground ice, depending upon the presence or absence of moisture. Perennial ground ice exists in small intergranular interstices or as larger discrete segregated bodies of various shapes and dimensions. In terms of large-scale surface configurations, ground ice is more important than permafrost, although the former does not exist without the latter, except in a deteriorating phase. Unfortunately, in planetary-science literature the term permafrost is frequently used as synonymous with ground ice.

Mars has experienced some degree of differentiation and presumably, therefore, some degree of degassing, both on a scale more limited than Earth. Even limited degassing by Mars presumably produced water, and a troubling question is what has happened to the martian water? The amount in the atmosphere or locked up in polar ice caps (Smoluchowski 1968 ) is distressingly small. Water dissociates in the martian atmosphere, and the hydrogen escapes readily (McElroy 1972), so some water has 
Annual Reviews

R www.annualreviews.org/aronline

wasted to outer space. Other water may be chemically combined in surface materials (Fanale 1976, Huguenin 1976). A further speculation is that much of the water never got to the surface but was captured as ground ice owing to the rigorous thermal environment of Mars, the current equatorial mean temperature being between $70^{\circ}$ and $80^{\circ} \mathrm{C}$ below zero. The possibility of martian ground ice is supported by some terrain features.

Many of the unusual and striking forms of the present martian surface in equatorial regions appear to be the product of large-scale collapse, which has produced a jumbled topography featuring tilted blocks and a highly fractured crust, termed chaotic terrain (Figure 2). Issuing from

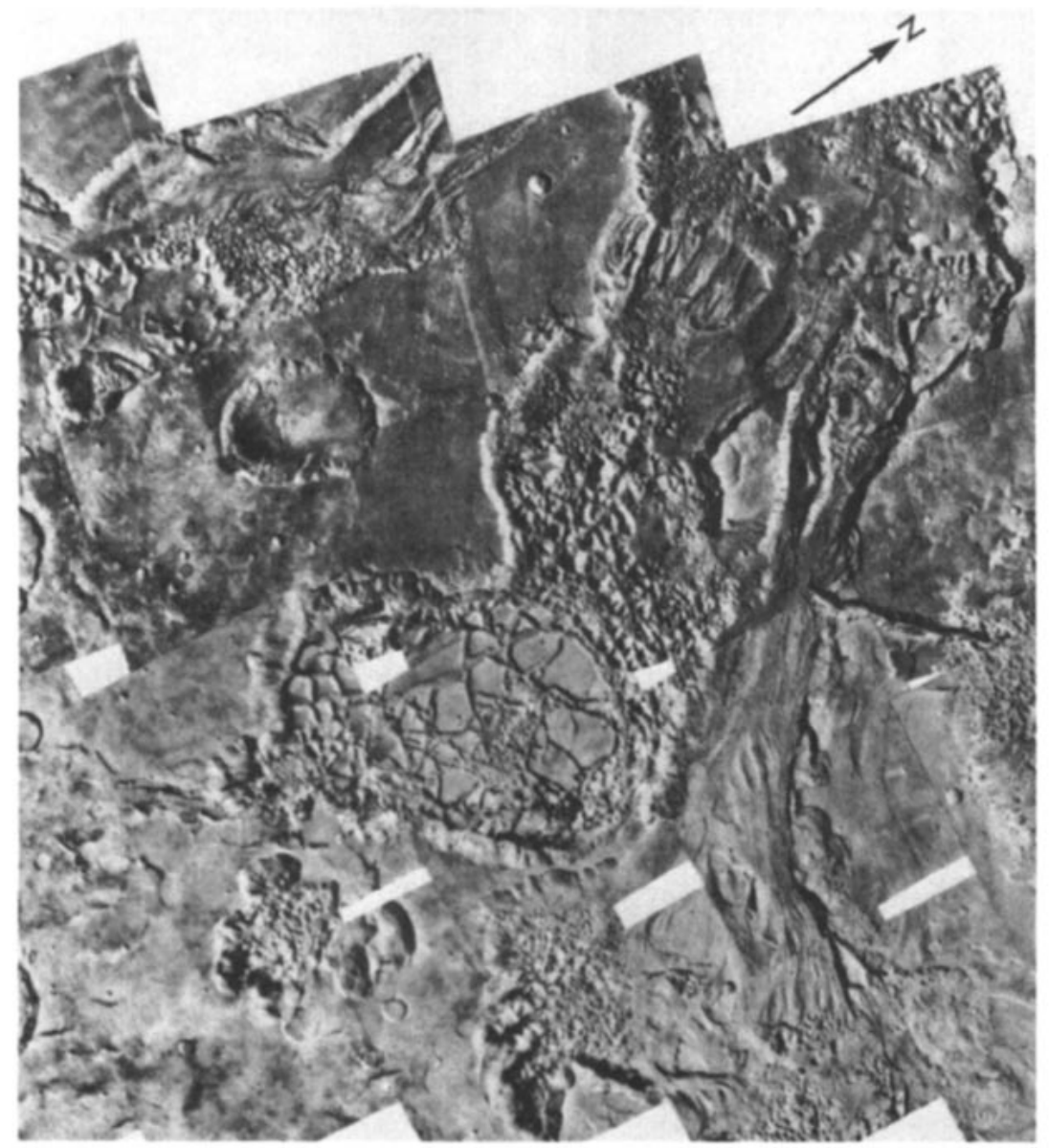

Figure 2 Photomosaic of collapsed chaotic terrain and large outflow channels displaying features resembling those created by huge terrestrial floods. Area viewed about $500 \mathrm{~km}$ wide. NASA photos, Viking 1-96, P-19131. 
some areas of chaotic terrain are large outflow channels (Milton 1973, Sharp \& Malin 1975, Masursky et al 1977) displaying features suggestive of huge floods (Baker \& Milton 1974, Baker 1978) that resemble the products of the Spokane (Bretz 1923, Baker 1973, Baker \& Nummendal 1978) and Bonneville (Malde 1968) floods of western United States. A reasonable although still highly speculative and not universally accepted interpretation (Wilson et al 1973) is that local melting of great masses of ground ice caused by geothermal anomalies or impacts (Maxwell et al 1973) generated large quantities of liquid water which broke forth to the surface making floods. Fluids other than water are more speculative (Milton 1974, Yung \& Pinto 1978).

The fretted terrains of Mars display features suggesting the action of a sapping process (Sharp 1973b, Masursky et al 1977, p. 4022). On Earth, sapping is a common product of ground-water seepage; on Mars the melting or evaporation of ground ice exposed on the face of steep declivities may be the primary cause. Carr et al (1977a, p. 4062) speculate that the extended flow of debris lobes ejected from martian impact craters may have resulted from included water produced by impact melting of ground ice. Many features on the martian surface, possibly caused by ground-ice deterioration, occur on a scale far larger than on Earth.

Some of the smaller forms produced on Earth by the intense freeze and thaw activity that occurs in the surficial active layer of frozen ground may exist on Mars, but they are much too small to be seen on orbiter photos, and none is recognized in photos returned by the Viking landers. On Earth the exceptional mobility of the thin layer of seasonally thawed material above permafrost creates landforms of smoothed, subdued, and rounded configuration. Some parts of the martian surface display similar characteristics on a larger scale (Balsamo \& Salsbury 1973). This is not absolute evidence for permafrost because a similar aspect can be created through mantling by pyroclastics or other air-borne debris. Convex rolls at the bottoms of some martian slopes could be the product of the flow and creep that occurs in the thin surficial debris mantle overlying permafrost on slopes. More impressive evidence of mass flow is provided by wide lineated debris streams (Figure 3) filling some martian valleys (Squyres 1978). These resemble the product of vigorous flow and creep produced by freeze and thaw and possibly testify to such activity on Mars, provided the martian environment at the time of their formation permitted liquid water at or near the surface.

The attempt to explain patterns of large polygonal cracks on parts of the martian surface by processes related to freeze and thaw and permafrost conditions (Masursky \& Crabill 1976) has not been widely accepted because of the large scale of the cracks. They may be of tectonic origin (Mutch et al 1976, p. 232-34, Strom et al 1975, p. 2482). 
R $\begin{aligned} & \text { Annual Reviews } \\ & \text { www.annualreviews.org/aronline }\end{aligned}$

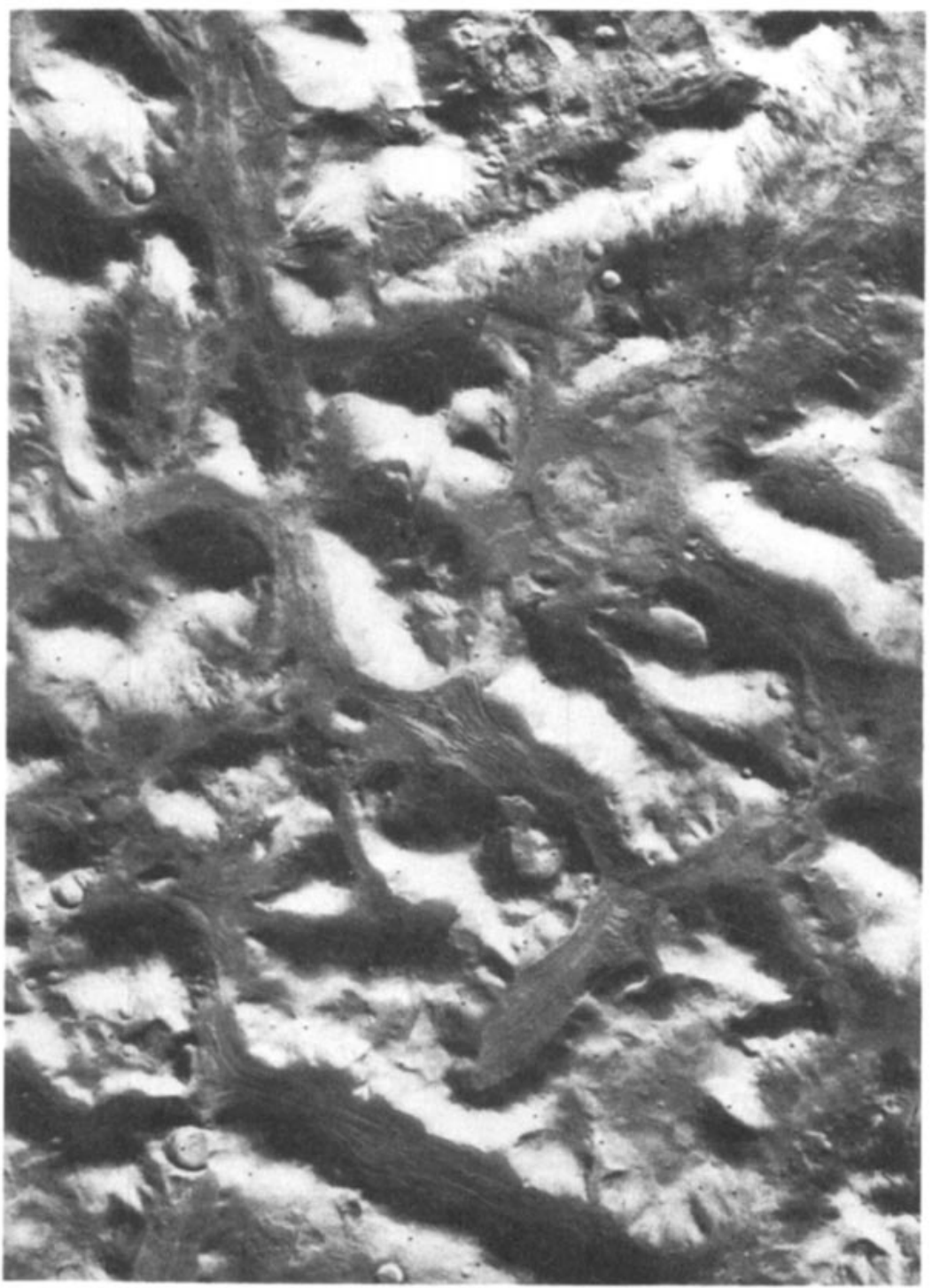

हี

$8 \stackrel{\infty}{1}$ 范 몬 竞 $8{ }^{\circ}$ अ 晃 $0<$ 吾出 吾嵒离 $\Omega$ of 듬 苍总

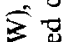
马욜 Z 菏 믕 . 这 总宽 究 总 呇 㟔 惫 它 옹은 $\stackrel{\circ}{2}$ $m$ $\stackrel{\infty}{\infty}$ 


\section{SHARP}

Mars is currently more than cold enough to have an extensive and deep permafrost. Whether or not it has the more important ingredient, ground ice, rests upon the controversial availability of liquid water. Without water, permafrost is more of a stabilizing factor than an active agent creating surface features. The role of $\mathrm{CO}_{2}$ ice as a substitute for water ice remains speculative (Lambert \& Chamberlain 1978). The fact that martian surface features resemble forms created by freeze and thaw and by conditions of permafrost and ground ice on Earth (Anderson et al 1967, 1972, 1973, Gatto \& Anderson 1975, Wade \& deWys 1968) could be employed as an argument favoring the existence of liquid water in significant quantities on or near the surface at some time during evolution of the planet.

\section{Sapping as a Geomorphological Process}

Planetary exploration, especially of Mars, has renewed interest in the efficacy and mechanisms of sapping, a surface process that causes steepening and recession of slopes by undermining at their base. This is a healthy influence, for sapping, although a long-recognized terrestrial process, has not fully received the attention it deserves.

The role of localized ground-water seepage (seepage sapping or spring sapping) in creating steep-head (box) canyons and amphitheaters on Earth is recognized (Jennings 1971, pp. 112-14). Cliff development and recession in areas of horizontally layered rock, sedimentary and volcanic, is also attributed in large part to sapping by seepage. Steep-walled, steepheaded gullies on gently rolling hillsides are more often the product of headward growth by seepage sapping than of surface runoff (Emmett 1968).

On Mars, the wide, flat-floored, steep-walled valleys, box-head canyons, amphitheaters, irregular cliffs, mesas, and buttes of fretted terrain all indicate the action of sapping (Sharp 1973b, Masursky et al 1977, p. 4022). The walls of the gigantic martian troughs (Sharp 1973a, Blasius et al 1977) display evidence suggestive of sapping and many of the abundant and huge martian landslides (Sharp 1973c, Luchitta 1978) have probably been set off by basal sapping. Dendritic canyons tributary to the large martian equatorial troughs and clearly controlled by sets of fractures in the crustal rocks (Figure 4) probably developed by some mechanism of headward growth, probably sapping. Spring sapping is judged a likely cause for other channels on Mars (Sharp \& Malin 1975, Masursky et al 1977, p. 4022).

The variety, abundance, and wide distribution of such forms in low and middle martian latitudes suggest that sapping may have been a more effective process in landform genesis on Mars than on Earth, although 
A Annual Reviews

www.annualreviews.org/aronline

the effectiveness of sapping on Earth may be underestimated because its products are so strongly overshadowed by the work of running water. Sapping on Earth is produced largely by ground water and only locally by deterioration of ground ice. On Mars the role of these two agents may be reversed.

\section{Ancient Earth Terrains and Features}

Renewed interest in states of the Earth's crust during its earliest evolution that may have been largely destroyed, masked, buried, or altered by subsequent events, conditions, and processes has been generated by

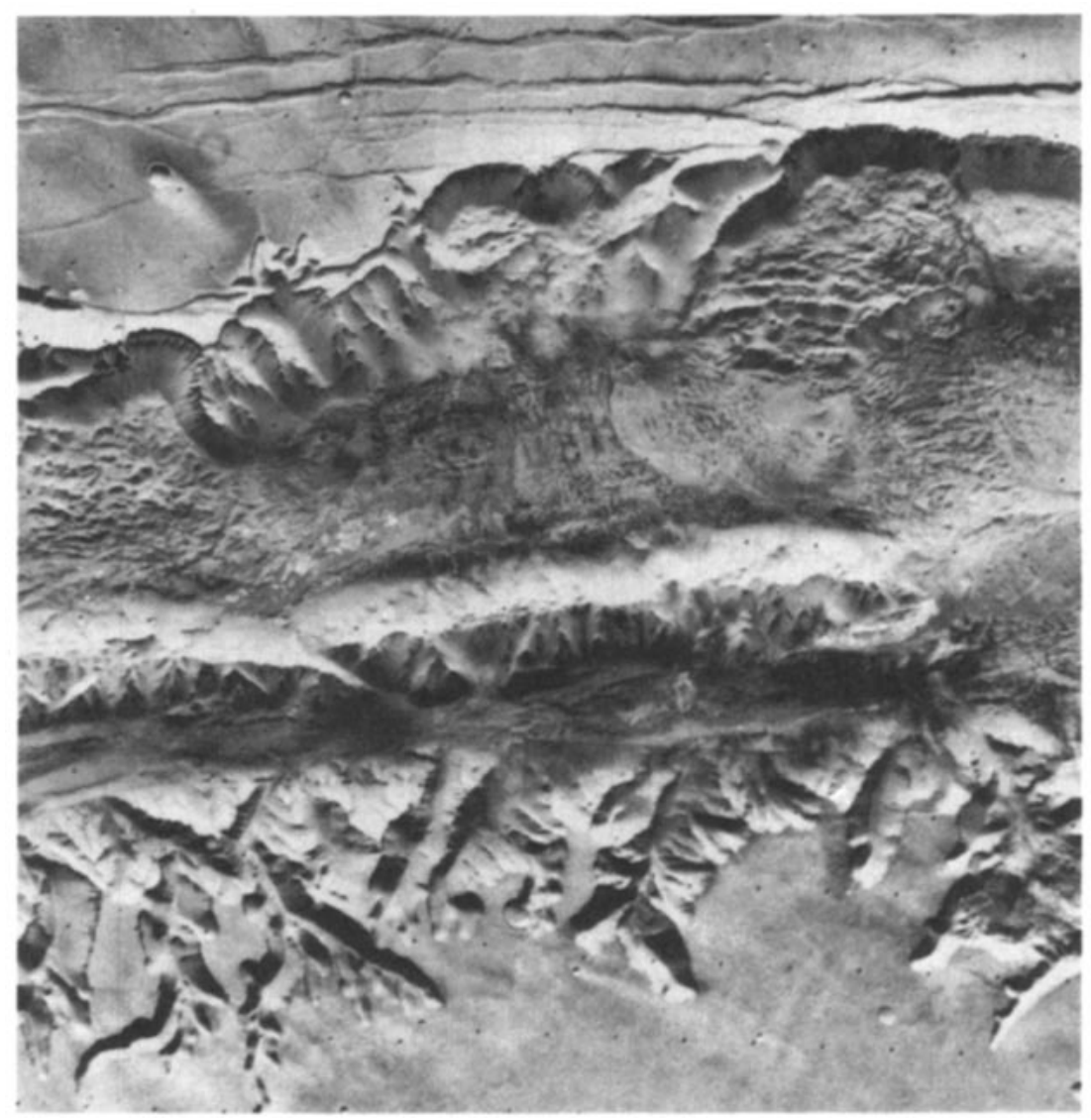

Figure 4 Photomosaic of large trough in Valles Marineris region of Mars. Far (north) wall scarred by huge slides and upland to south dissected by canyon system probably created by fracture-controlled sapping. Trough approximately $100 \mathrm{~km}$ wide. NASA photos, Orbiter I, Viking 1-80, P-17872 (63A31-46). 


\section{SHARP}

space exploration. The Earth's crust was almost surely subjected to the same initial heavy bombardment by meteoroidal bodies recorded by the surfaces of Moon, Mars, and Mercury, and it must have looked much like those planets in its earliest stage. Not only have the surface features of this bombarded crust been eliminated by weathering and erosion, which is not surprising, but also the deeper scars of large impacts are so far unrecognized. Scars of large, but younger, impacts may be represented by some of Earth's more enigmatic crustal structures (Dietz 1961, 1963, 1964). However, the evidence of very large early impacts, so spectacularly displayed on other planetary surfaces, seems to be gone, or so greatly modified as to be unrecognizable. The layer of impact brecciated rock, widely distributed within the lunar uplands and presumably also well developed on Mars and Mercury, has been so modified by metamorphic processes on Earth as to be unrecognizable.

The martian surface displays types of terrains or features with no known counterpart on Earth, present or past. Examples are the huge equatorial troughs of the Valles Marineris region or the complex rectilinear pattern of chasms in Labyrinthus Noctus. Earth does have limited areas of small-scale chaotic terrain, but nothing comparable in area or scale to the chaotic terrains of Mars, or like the etched terrain of the southern martian subpolar area. Martian fretted terrain has aspects similar to some terrestrial plateau country, but the rocks look different and the genetic processes may not have been the same.

This does not mean that Earth never had such terrains, but evidence of them has not been recognized. Especially intriguing is the evidence of major collapse of large areas on the martian surface. This may well have occurred on Earth, but so far we may not have looked for the effects on a large enough scale.

\section{ON-GOING DEFORMATION OF EARTH'S CRUST}

Current concern with earthquake hazards has created an awareness of the inadequacies of the short human record of seismic activity. Allen (1975) has shown how to extend this record backward into the Holocene (the last 11,000 years) by study of small-scale, subtle surface features along fault traces (micro-morphology) and by analysis of relationships within layered materials immediately underlying the surface in fault zones (micro-stratigraphy). Examples of the use of micro-stratigraphic sections, of micro-structures in sediments, and of micro-morphological features are treated here. An increasing interest in current deformation of the Earth's crust is clearly manifest, witness the symposia on recent crustal movements (Pavoni \& Green 1975, Whitten et al 1979). Changes attend- 
ing subsidence generated by withdrawal of underground fluids, often centered in heavily urbanized areas, also merit attention (Poland \& Davis 1969, Geerstman 1973).

\section{Seismic Activity and Micro-Morphology}

Gilbert (1928) summarized observations, going back at least half a century, that demonstrated the value of scarplets in alluvium and other Holocene deposits for deciphering the history of recent activity along faults. The detailed forms of such scarplets have been accorded particular attention during the past decade.

Slemmons, Cluff, and associates (Slemmons 1967, 1969, 1975, Slemmons et al 1969 , Oakeshott \& Greensfelder 1972) in sparsely published studies have used a technique of low-altitude, low-sun-angle air photography to identify many previously unrecognized scarplets on the alluvial floor of Owens Valley just west of the Sierra Nevada in California. Particular attention has been given to scarplets with compound profiles (facets of different slope) as a means of identifying recurrent movements. Using all possible variations of time of day and season of the year, they have been able to photograph scarps under illumination-angle differences as great as $45^{\circ}$. Full use of this lighting spectrum has provided information on scarplet morphology not usually available from ground-based inspection. Scarps related to the 1872 Owens Valley earthquake proved to have a mean declinity of $34^{\circ}$, and two earlier families of scarps, or scarp facets, were distinguished, one sloping an average $15^{\circ}$ and a still older group at 5-10 . Buckman \& Anderson (1979) also address the matter of change in scarp height and slope with age.

Gary Carver (1970, 1975, Carver et al 1969) used Slemmons's methods in a study of recent tectonics within Owens Lake basin at the south end of Owens Valley. There scarps in well-consolidated glacial outwash were as steep as $70-80^{\circ}$. In addition to having gentler slopes, older scarps had rounded brinks, and many displayed a crestal bald strip, easily recognized from the air and presumably formed by rain beat and thread- and sheet-flow of water. Much of the surficial mantle bordering Owens Lake is a mixture of lacustrine and fluvial deposits, which are susceptible to sliding during seismic events. Thus, many of the surface scarplets and associated graben are regarded by Carver as secondary products of mass movement rather than primary tectonic forms.

Carver uses compound scarps with facets of different slope to identify separate episodes of movement, but he also gives attention to small alluvial fans at a scarp base. These fans and the layers of material composing them would appear to merit more careful study in other areas. Sieh (1978b, pp. 1428-34) made a careful study of three sets of small 


\section{SHARP}

alluvial fans offset along the 1857 break on San Andreas fault just off Soda Lake Road, $3 \mathrm{~km}$ northwest of Highway 166 near the southern end of Carrizo Plain in Kern County, California. By measuring the offset of fan heads from source gullies, he demonstrates a $6.5-\mathrm{m}$ right-lateral displacement in 1857 (Figure 5). Comparison of debris volumes of pre- and post-1857 fans suggests that the preceding major offset occurred here about $1470 \pm 40$ A.D. This is consistent with data gathered elsewhere along the fault (Sieh 1978a).

Study of laterally offset fans can be made only on faults with a significant lateral-slip component of movement. However, investigation of deposits composing small fans, superimposed one on top the other, along the base of faults with only vertical displacements might prove equally rewarding in deciphering fault-movement history.

Wallace (1977), working in an area of historical faulting, Lake Lahontan shorelines, and related deposits in north-central Nevada, has refined and extended earlier studies of scarp morphology in relation to seismic history. Using principles of slope morphology and evolution, he identifies elements within the scarp as the free face, debris slope, and wash slope (Figure 6). Slopes of the free face usually range between $45^{\circ}$ and overhanging, depending upon material, compaction, and binding by roots. Scarp brinks remain sharp as long as a free face exists, but they become rounded once the free face disappears. Debris slopes are at the angle of repose, mostly in a range of $34-37^{\circ}$, depending upon material. Wash slopes decline from $15^{\circ}$ near their head to $3^{\circ}$ near the base. If debris

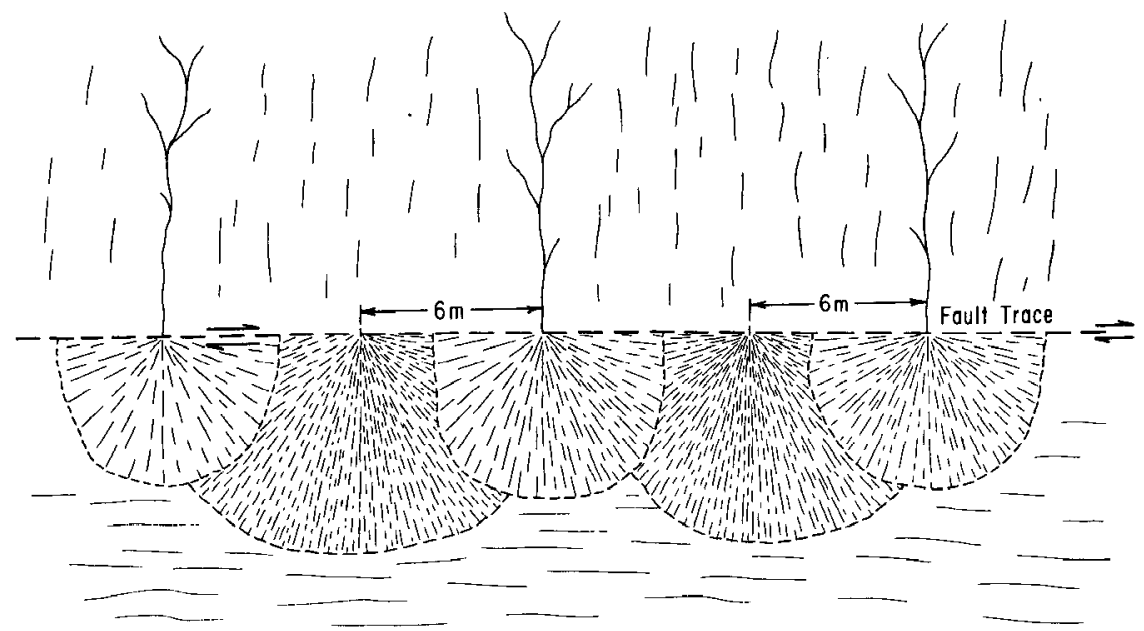

Figure 5 Planimetric sketch of small alluvial fans at hillslope base offset by 1857 lateral displacement on San Andreas fault, modified from Sieh (1978b). 
composing the scarp face is heterogeneous, including coarse elements, armoring of slopes by larger fragments can become a significant factor. Gullies created by through-flowing drainage need to be treated separately from gullies originating on the scarp face as to their respective roles in scarp modification.

In general, changes on the scarp face occur primarily by gravitycontrolled spalling (loosening and fall of individual fragments) and wash (rain beat, thread flow, sheet wash). Material composing the scarp is obviously a factor (Pease 1979), and climatic environment is important (Wallace 1979).

A scarp face progresses through a sequence of evolutionary stages ranging from an initial $100 \%$ gravity control to $90 \%$ wash control after a million years. Allowing for differences in material, a debris-controlled slope is usually the dominant feature after a century, and a combination of debris- and wash-controlled slopes appear in 1000-2000 years. Reduction in slope steepness occurs as wash control encroaches more strongly on the debris-controlled slope. Within 10,000 years, rounding of the scarp brink becomes significant. Some measure of the influence of material is shown by a $2-\mathrm{m}$ recession in 20 years of the free face of an historical scarp in poorly indurated fanglomerate compared to a nearby scarp in well-indurated colluvium (ill-sorted slope mantle) which showed little significant modification in 60 years.

Histograms of historical scarp slopes in north central Nevada show bimodal peaks at about $30^{\circ}$ and $85^{\circ}$ within a widely dispersed range from $15-90^{\circ}$. The dispersal of values become narrower, $10-35^{\circ}$, and unimodal with age, as a shift to lower slope angles occurs. A nearsymmetrical unimodal peak at about $25^{\circ}$ develops in less than 1200 years.

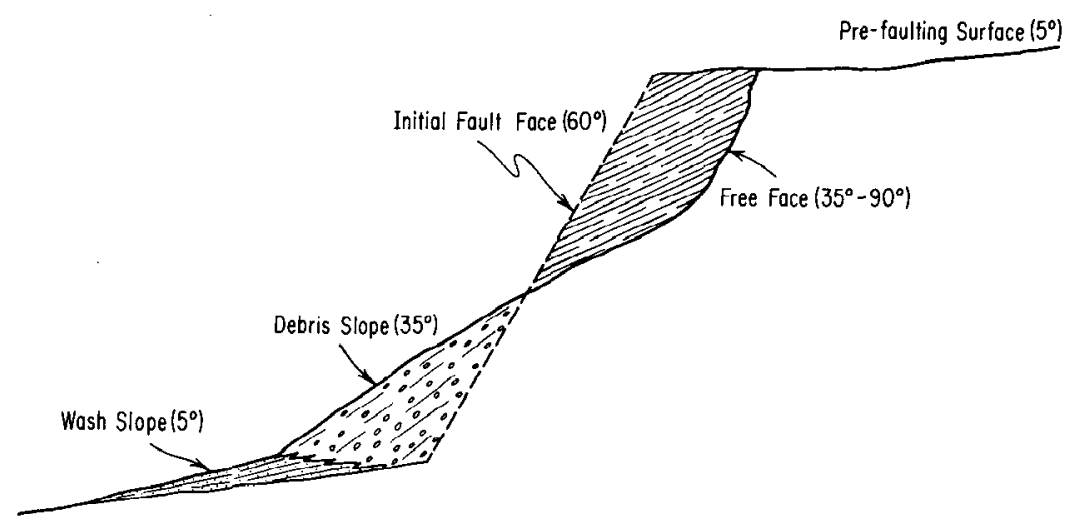

Figure 6 Essential morphological elements of a partly degraded recent fault scarplet, modified from Wallace (1977). 


\section{$248 \quad$ SHARP}

At greater than 12,000 years the spectrum, $5-25^{\circ}$, of slopes is asymmetrical but unimodal at roughly $15^{\circ}$. This peak shifts to about $12^{\circ}$ for scarps much greater than 12,000 years. The bimodal histograms of historical scarps reflects the fact that a free face and a gravity-controlled debris slope are both present. The free face disappears within a few hundred, or at most a few thousand, years. The width of the crestal break becomes greater with age, and on scarps older than 12,000 years the break in slope at the toe can be greater than the break at the brink of the scarp.

Morphological features are also created by faulting in areas contiguous to but not directly along the line of faulting, and they can be used to establish the sequence and sometimes the dates of movements. Among such features are knick points (breaks in longitudinal stream profile) and terraces along drainage lines crossing the fault trace, as well as warped, tilted, or displaced shorelines or other normally planar features.

One objective of determining the detailed history of activity along a fault is to ascertain the frequency of seismic events, or the recurrence interval (Lamar et al 1974, Weber 1979). This is difficult through use of micro-morphological features alone because good time control is usually lacking. For example, Wallace $(1968,1969)$ and Sieh (1978b) working with laterally offset stream channels along San Andreas fault have successfully determined the amount of recurrent displacements, but accurate measurement of recurrence intervals largely eludes them. Some feel for relative values can be obtained from the delicate interplay between incision, alluviation, and bench-and terrace-formation related to individual seismic events (Wallace 1977, p. 1275). Such analyses usually involve subtle and sometimes complex interpretations.

Carver (1970, pp. 74-85) has attempted to use tilting of Owens Lake shorelines by faulting to calculate recurrence intervals of major earthquakes. He concludes that events about the size of the 1872 Owens Valley shock $(8.3 \mathrm{M})$ have occurred in this region about every 1000 years, between extremes of 590 and 1540 years. Although the calculation involves an uncertain and sensitive assumption of constant tilt rate, it is an interesting approach.

\section{Seismic Activity Recorded by Micro-Stratigraphy}

Work by Clark et al (1972) on Borrego Mountain earthquake of 1968 and by Sieh (1978a) on San Andreas fault at Pallett Creek, both in southern California, shows that the micro-stratigraphy of surficial materials can extend an historical record of faulting backward by centuries, even millenia. Dating of layers within deposits is fundamental to successful micro-stratigraphic work. This can be accomplished by historical records, 
${ }^{14} \mathrm{C}$ dating of associated organic materials, relationship to lake shorelines and associated deposits or glacial moraines and outwash, identifiable volcanic ash layers, tree rings, lichen, soil zones, and sedimentation rates among other methods.

Clark and associates excavated trenches across the 1968 break on Coyote Creek fault near Borrego Mountain in easternmost San Diego County to expose underlying surficial materials. Coyote Creek fault is a branch of San Jacinto fault, historically the most active seismic structure in southern California. The excavation showed progressively greater displacement of older strata with increasing depth along the fault plane as it cut through deposits of Holocene Lake Cahuilla. The oldest dated layer, 3000 years B. P. (before present), is offset vertically, including bending by drag, 3 times more $(1.7 \mathrm{~m}$ vs $0.56 \mathrm{~m})$ than the base of the youngest ( 860 years B. P.) dated layer. Abundant freshwater snail and clamlike shells provide ${ }^{14} \mathrm{C}$ dates at various levels. Reliability of these dates was checked with ${ }^{14} \mathrm{C}$ ages obtained from mussel shells, charcoal, and calcareous tufa (lakeshore $\mathrm{CaCO}_{3}$ ) in Lake Cahuilla deposits at other sites. The data support a conclusion that the recurrence interval for seismic events of the approximate magnitude of the 1968 quake (6.8) is roughly 200 years \pm 60 to 70 years.

Sieh studied, in painstaking detail, thicker accumulations of marsh deposits, silt, sand, and gravel with interlayers of peat, exposed in natural and artificial excavations along the bank of Pallett Creek on San Andreas fault north of San Gabriel Mountains in Los Angeles County. Age relationships were established by ${ }^{14} \mathrm{C}$ dating of peat and calculation of sedimentation rates for peat $(1.4 \mathrm{~mm} /$ year $)$ and silt $(1.9 \mathrm{~mm} /$ year $)$. Displaced strata and associated sand-boil structures provided evidence for 9 major seismic events since the Sixth Century AD. The latest was the 8.25 magnitude 1857 Fort Tejon earthquake, and 6 of the preceding 8 events were seemingly of similar size. The recurrence intervals of the 9 major events are bimodally distributed at 100 and 230 years, with an average of 160 years. Nine data points do not make a valid statistical sample, but they are better than just one (the historical record), and the limits of 100 to 230 years for the recurrence of large earthquakes along this reach of the San Andreas fault, inactive since 1857, is a useful parameter.

\section{Intra-Stratigraphic Structures of Seismic Origin}

Aside from actual displacement of strata along a fault plane, other structures generated by seismic shocks within soft sediments can be used to date earthquakes. Such structures have the advantage of wider geographic distribution, as they need not be confined to the fault zone. 
Sims (1975) capitalized on the opportunity to study bottom sediments in Van Norman Reservoir when it was emptied following the San Fernando (California) earthquake of 1971 (magnitude 6.6). These sediments, accumulated during the 56-year life of the reservoir, displayed internal deformation at three levels. The structures included load casts (local depressions into an underlying layer by more competent materials), small intra-layer folds, heave ups, contorted laminae, and pseudo-nodules. This type of feature is most likely to develop by plastic deformation within a liquified host material, and Sims judged that they formed in a sediment layer close to the water interface.

Four moderate to large earthquakes $(1930,1933,1952$, and 1971) occurred within contiguous southern California during the life of the reservoir. From the thickness of material between deformed layers and estimated rates of accumulation, Sims concludes that the 1930, 1952, and 1971 events generated the 3 zones of deformation observed.

A search for deformed zones within Holocene sedimentary accumulations in other areas of historical seismic activity has revealed 5 deformed layers within Lake Cahuilla deposits near Brawley in Imperial Valley (California) and 14 deformed layers, of possible seismic origin, in finely layered clays of Puget Sound (Washington). Sieh (1978a) used sand-boil structures (mushroom-like extrusions of liquified sand formed during earthquakes) to establish the relative position of specific seismic events within the beds at Pallett Creek. Lamar et al (1979) have recognized possible seismogenic deformation within young sediments of nowdrained Kern Lake in San Joaquin Valley, California. A continued and expanded search for zones of seismogenic deformation in other Holocene accumulations would seem a desirable endeavor.

\section{Micro-Chronology}

A necessary element in micro-stratigraphy and micro-morphology is a sense of time. The advent of ${ }^{14} \mathrm{C}$ dating was a great boon to this need, and other methods for measuring short time intervals and dates have been or are being developed and applied. These include ${ }^{40} \mathrm{~K} /{ }^{40} \mathrm{~A},{ }^{210} \mathrm{~Pb}$, uranium daughter products, amino acids, fluorine impregnation, hydration rims on volcanic glass, tephrochronology, and paleomagnetism. Some of these procedures are secondary in the sense that they depend upon an absolute datum furnished by radioactive clocks. Tephrochronology and paleomagnetism are intimately tied to micro-stratigraphy and have the advantage of regional extent compared to spot measurements.

Tephra (pyroclastics) includes all fragmental material ejected by volcanic explosions. Layers of tephra incorporated within other Quaternary materials have long been used as a basis for correlation and relative 
dating (Swinford 1949, Wilcox 1965, D. G. W. Smith \& Westgate 1969, Izett et al 1970, H. W. Smith et al 1977a, b, Porter 1978, as examples). Modern chemical and petrological analyses provide means of fingerprinting tephra layers from different sources more effectively (Borchardt et al 1971), and improvements in precision of ${ }^{40} \mathrm{~K} /{ }^{40} \mathrm{~A}$ analyses of younger materials have made absolute age assignments increasingly reliable.

Tephrochronology is most useful to micro-stratigraphers working near or downwind from volcanic centers active within the last one or two million years, but layers of fine volcanic ash have been singularly identified 1000 miles from their source. Tephrochronology appears destined for wider and more effective use in the future. Recent research shows that variations in the strength and reversals of Earth's magnetic field (paleomagnetism) can be used in correlation of young as well as older deposits (Opdyke et al 1977, Johnson 1975, Mörner 1977, Vitorello \& van der Voo 1977, Manabe 1977, Davis et al 1977, Maenaka et al 1977).

The use of plants, mostly trees, in studies of surface processes and landform evolution, a technique long practiced by a few botanically inclined investigators (Cooper 1923, 1937, 1939, Heusser 1954, 1956, Lawrence 1950, 1958a,b, Sigafoos 1964, among others) is now enjoying renewed attention and wider application (Alestalo 1971, La Marche 1968, Page 1970, Shroder 1978, Zoltai 1975). La Marche \& Wallace (1972) and Sieh (1978b) have recently used dendrochronology to date movements on San Andreas fault by asymmetry or compression of tree rings resulting from tilting or disturbance of trees.

\section{Geodesy and Recent Deformation}

Recently, a strong renaissance of interest in using geodesy as a means of detecting, measuring, and understanding current deformation of the Earth's crust has occurred (Kaula 1978, pp. 20-22). MacDoran (American Geophysical Union Meeting 1979) commented specifically upon exciting geophysical applications of the dusty old discipline of leveling.

The vast store of leveling and triangulation data gathered over many decades by public agencies and bureaus is proving to be a virtual gold mine of useful information (Castle et al 1974, 1975). An example is the dramatic discovery of southern California's "Palmdale Bulge" (Castle et al 1976), perhaps too hastily christened, as additional investigations (Bennett 1977, Castle et al 1977) show it to be an elongated ridge extending from Point Arguello on the coast at least $580 \mathrm{~km}$ eastward to the Arizona border with the point of greatest uplift, $45 \mathrm{~cm}$, between TwentyNine Palms and Amboy, a considerable distance east of Palmdale. The bulge (or ridge) began to rise in the early 1960s, culminated in 1974, and 
had collapsed about 50 percent by 1977 . Evidence of earlier upwarps in this general area are gleaned from still older surveys.

Analyses of old survey data from other parts of southern California are yielding useful tectonic information (Thatcher 1979) and may eventually produce additional surprises. Such endeavors will be interesting to monitor (Buchanan-Banks et al 1975). A study by Wood \& Elliott (1979) reveals an uplift with westward tilting of the northern part of the Peninsular Ranges block involving elevation changes as great as $0.4 \mathrm{~m}$ within the earliest 20th Century. Thatcher (1976) shows how geodetic data may give premonitory warning of possible thrust-fault earthquakes (Castle et al 1975). Although the examples cited are drawn from southern California, similar investigations are under way in other parts of the US (Isachsen 1975, Brown \& Oliver 1976, Reilinger et al 1977) and in many other parts of the World, including Alaska, Poland, Russia, India, Japan, New Zealand, Switzerland, and South America.

Aside from old methods and old data, geophysicists working on problems of crustal strain and seismicity (Meade 1975) have been quick to appreciate the value of various modern techniques of electronic surveying (Huggett \& Slater 1975, Savage et al 1973, 1978, Prescott \& Savage 1976) that appeared following World War II (Ewing \& Mitchell 1970 , p. 108, Tomlinson \& Burger 1977). These newer systems include the use of modulated light waves (geodimeter), pulsed radio waves (tellurometer), laser ranging to satellites including Moon (Bender \& Silverberg 1975), radio doppler, and various types of radio and radar altimeters. Recently, radio interferometry employing extra-galactic radio sources, so distant that they behave as fixed points, has been used over very long baselines (Coates et al 1975, Whitcomb 1976).

Some of these methods measure only distance, resulting in trilateration. (Prescott \& Savage 1976) in place of the older procedure of measuring angles (triangulation). However, ranging techniques yield threedimensional data that can be used to determine elevation differences. The virtue of most new methods is the speed with which they can be executed and the long distances over which they can operate with high accuracy.

Earth scientists working in areas of current tectonic activity easily become preoccupied with faulting and its various manifestations. Warping is a much more subtle tectonic process, less dramatic and often less dangerous or damaging. Nonetheless, it is interesting, more extensive in area, and in urbanized regions economically significant.

Antecedent warping can be detected by geological relationships, if a suitable reference datum, such as the Funeral basalt of the Death Valley region, exists. Landforms, such as alluvial fans, can also record warping (Hooke 1972). 
One good method of detecting and measuring current warping is by the time-proven procedure of tiltmetering. Long-period horizontal pendulum seismometers, borehole pendulums, wet tubes, telescopic spirit leveling, mercury pools, and tide gauges can all be used as tiltmeters (Rikitake 1976, pp. 126-49). The antecedent eastward tilting of the Death Valley block, indicated by geomorphological and lacustral evidence (Hunt 1966, pp. 46-47, Hunt \& Maybe 1966, p. 100), was confirmed by installation of simple tiltmeters (Greene 1966). Tiltmeters are now being improved (Eaton 1959, Huggett et al 1976) and more widely deployed in areas of known or suspected crustal instability. They have long been used in Hawaii as part of the eruption-prediction program.

Like all human procedures, tiltmetering suffers from the brevity of the historical record, and geologists do well to look for natural tiltmeters of longer record. Ponded water bodies can be employed as tiltmeters (Sirén 1951), witness recent studies of Salton Sea in Imperial Valley (Wilson \& Wood 1980). Using records of water-level staff gages maintained at 3 sites along the shore for over 25 years, a 1952-to-1972 downward tilting to the southeast of $11 \mathrm{~cm}$ over a $38-\mathrm{km}$ distance was demonstrated. A reversal in direction of tilt set in after 1972. Hunt (1966, pp. 46-47) used the salt pan of a dessicated lake about 2000 years old to demonstrate tilting. Shoreline warping of more ancient vintage was long ago recognized by Gilbert (1890) for Lake Bonneville and for the glacial great lakes by Upham (1884) and Leverett \& Taylor (1915), among others.

Geomorphologists and limnologists have probably not given sufficient attention to the micro-features of lake shorelines as possible indicators of ongoing tilting. A search for small-scale features indicating emergence along one reach of a lake shoreline and of submergence on the opposing shore may require patience and a sharp eye for detail but could be rewarding. Shores subject to ice shove may be unsatisfactory.

\section{CONCLUSIONS}

Interest in processes shaping the surface of Earth has been stimulated and broadened by exploration of other planetary bodies and by man's increasing desire to live as comfortably and economically as possible in harmony with the natural environment and in reasonable safety with respect to natural geological disasters, such as earthquakes, landslides, floods, volcanic eruptions, and related phenomena.

Since features seen on other planetary surfaces are best understood in terms of earthly analogues, space exploration has stimulated interest among planetologists in such terrestrial phenomena as volcanism, work of the wind, huge catastrophic floods, perennially frozen ground 


\section{SHARP}

(permafrost), ground ice, sapping as an erosional process, and mass movements (landslides, creep, earthflows).

Increased interest in volcanology has been generated by the number and variety of volcanic features (cones, domes, rilles, lava fields, flow patterns, and above all craters and caldera) seen on the surfaces of other planetary bodies including Moon, and now the satellites of Jupiter. This interest has beneficially increased and broadened the study of volcanic forms on Earth. Not enough attention has yet been given to the possible role of tephra blankets (fragmented volcanic materials) in landscape evolution on extraterrestrial bodies. Such blankets may have been emplaced upon and partly or wholly stripped from underlying surfaces.

The likelihood of extensive eolian erosion on Mars has sparked a profitable search for more and larger features of eolian erosion on Earth. Abundant large erosional channels on Mars have created greater appreciation of phenomena related to huge catastrophic floods on Earth, such as the Spokane and Bonneville events of western United States.

Widespread evidences of collapse, extensive flooding, topographic sapping, and creeping surface debris on Mars have broadened interest in frozen ground, ground ice, and the freeze-thaw process, matters heretofore of concern principally to a small group of specialists. Recognition of the role of these processes and conditions in shaping terrestrial landscapes has been enhanced by interest in their possible effects on other planets.

The surface of Earth, in its earliest stage, must have looked much like the present surfaces of Moon, Mars, and Mercury, although vestiges of this early state, including a thick and widespread mantle of breccia (broken rock), have so far escaped detection owing to reconstitution by erosion, deposition, and metamorphism. The huge scale of features visible on other planetary surfaces should motivate geologists to look at Earth through wider eyes.

In the realm of man's desire to live in greater harmony with nature, micro-morphology, micro-stratigraphy, and micro-chronology are playing ever more creative roles. For example, such studies show the recurrence interval for 6-7 magnitude earthquakes on Coyote fault of the San Jacinto system (California) to be on the order of $200 \pm 70$ years, and on San Andreas fault, north of San Gabriel Mountains (California), to average 160 years within limits of 100 to 230 years for quakes of magnitude 8 .

The deciphered history of displacements on active faults is being extended back into prehistoric times by study of fault-scarp forms (micromorphology), of the succession of deposits laid down at the base of such scarps (micro-stratigraphy), and by the offset of features, such as small alluvial fans, along the traces of lateral-slip faults. Seismogenic deforma- 
tion of soft sediments is proving useful in deciphering the history of fault displacements in areas remote from the actual fault zone.

Measurements of short intervals of time (micro-chronology) are essential to all micro-morphological and micro-stratigraphic investigations. Geochemical methods of short-time measurements, other than ${ }^{14} \mathrm{C}$, are being developed and applied. Paleomagnetism and finger-printed layers of volcanic ash are providing means of correlating layers within young surficial materials.

Current deformation of segments of Earth's crust by warping and creep are probably more ubiquitous than usually perceived. Terra is not so firma. Modern geodectic techniques, as well as vast accumulations of older geodectic data, are leading to the discovery and determination of areas and rates of current tectonic deformation, witness the Palmdale Bulge.

The need, opportunity, and supporting techniques for study of features and processes on the terrestrial surface have never been greater than at present.

\section{Literature Cited}

Alestalo, J. 1971. Dendrochronological interpretation of geomorphic processes, Fennia 105: $1-40$

Allen, C. R. 1975. Geological criteria for evaluating seismicity. Geol. Soc. Am. Bull. $86: 1041-57$

American Geophysical Union. 1979. Southern California anomalies, EOS, Trans. Am. Geophys. Union 60:50

Anderson, D. M., Gaffney, E. S., Law, P. F. 1967. Frost phenomena on Mars. Science 155:319-22

Anderson, D. M., Gatto, L. W., Ugolini, F. 1972. An antarctic analog of martian permafrost terrain. Antarctic J. US 7:11416

Anderson, D. M., Gatto, L. W., Ugolini, F. 1973. An examination of Mariner 6 and 7 imagery for evidence of permafrost terrain on Mars. In Permafrost: The North American Contribution to the Second International Conference, pp. 449 508. Natl. Acad. Sci. 783 pp.

Arvidson, R. E. 1972. Aeolian processes on Mars: Erosive velocities, settling velocities, and yellow clouds. Geol. Soc. Am. Bull. 83:1503-8

Arvidson, R. E., Coradini, M., Carusi, A., Coradini, A., Fulchignomi, M., Federico, C., Funiciello, R., Salomone, M. 1976. Latitudinal variation of wind erosion of crater ejecta deposits on Mars. Icarus 27: 503-16

Baker, V. R. 1973. Paleohydrology and sedi-

mentology of Lake Missoula flooding in castern Washington. Geol. Soc. Am. Spec. Pap. 144.79 pp.

Baker, V. R. 1978. The Spokane Flood controversy and the martian outflow channels. Science 202: 1249-56

Baker, V. R., Milton, D. J. 1974. Erosion by catastrophic floods on Mars and Earth. Icarus 23:27-41

Baker, V. R., Nummendal, D., eds. 1978. The Channeled Scabland. Office of Planetary Geology Programs, NASA. $186 \mathrm{pp}$.

Ball, J. 1927. Problems of the Libyan Desert. Geogr. J. 70:32-34

Balsamo, S. R., Salsbury, J. W. 1973. Slope angle and frost formation on Mars. Icarus 18:156-63

Belcher, J. D., Veverka, J., Sagan, C. 1971. Mariner photography of Mars and aerial photography of Earth: Some analogies. Icarus $15: 241-52$

Bender, P. L., Silverberg, E. C. 1975. Present tectonic-plate motions from lunar ranging. Tectonophysics 29:1-7

Bennett, J. 1977. Palmdale "Bulge" update. Calif. Geol. 30:187-89

Black, R. F. 1976. Features indicative of permafrost. Ann. Rev. Earth Planet. Sci. 4:75-94

Blackwelder, E. 1931. The lowering of playas by deflation. Am. J.Sci. $21: 14044$

Blackwelder, E. 1934. Yardangs. Geol. Soc. Am. Bull. 45: 159-66

Blasius, K. R., Cutts, J. A., Guest, J. E., 
Masursky, H. 1977. Geology of the Valles Marineris: First analysis of imaging from the Viking I orbiter primary mission. $J$. Geophys. Res. 82:4067-91

Borchardt, G. A., Harvard, M. E., Schmitt, R. A. 1971. Correlation of volcanic ash deposits by activation analysis of glass separates. Quat. Res. 2:247-60

Bretz, J H. 1923. The channeled scabland of the Columbia Plateau. J. Geol. 31: $617-49$

Brown, L. D., Oliver, J. E. 1976. Vertical crustal movements from leveling data and their relation to geologic structure in the Eastern United States. Rev. Earth Space Phys. 14:13-35

Buchanan-Banks, J. M., Castle, R, O, Ziony, J. I. 1975. Elevation changes in the central Transverse Ranges near Ventura, California. Tectonophysics 29 : $113-25$

Buckman, R. C., Anderson, R. E. 1979. Estimation of fault-scarp ages from a scarp-height-slope-angle relationship. Geology 7:11-14

Carr, M. H. 1973. Volcanism on Mars. $J$. Geophys. Res. 78: 4049-62

Carr, M. H. 1974a. The role of lava erosion in the formation of lunar rilles and Martian channels. Icarus 22:1-23

Carr, M. H. 1974b. Tectonism and volcanism of the Tharsis region of Mars. J. Geophys. Res. 79: 3943-49

Carr, M. H., Crumpler, L. S., Cutts, J. A., Greeley, R., Guest, J. E., Masursky, H. 1977a. Martian impact craters and emplacement of ejecta by surface flow. $J$. Geophys. Res. 82:4055-65

Carr, M. H., Greeley, R., Blasius, K. R., Guest, J. E., Murray, J. B. 1977b. Some martian volcanic features as viewed from the Viking orbiter. J. Geophys. Res. 82: 3985-4015

Carr, M. H., Schaber, G. G. 1977. Martian permafrost features. J. Geophys. Res. 82: 4039-54

Carver, G. A. 1970. Quaternary tectonism and surface faulting in the Owens Lake Basin, California. Tech. Rep. AT-2. Univ. Nevada, Mackay Sch. Mines. 103 pp.

Carver, G. A. 1975. Shoreline deformation at Owens Lake. Calif. Geol. 28:111

Carver, G. A., Slemmons, D. B., Glass, C. E. 1969. Surface faulting patterns in Owens Valley, California. Geol. Soc. Am. Abstr. Programs. 1:9-10 (Abstr.)

Castle, R. O., Alt, J. N., Savage, J. C., Balazs, E. I. 1974. Elevation changes preceding the San Fernando earthquake of February 9, 1971. Geology 2:61-66

Castle, R. O., Church, J. P., Elliott, M. R., Morrison, N. L. 1975. Vertical crustal movements preceding and accompanying the San Fernando earthquake of February 9, 1971: A summary. Tectonophysics 29: $127-40$

Castle, R. O., Church, J. P., Elliott, M. R. 1976. Aseismic uplift in southern California. Science 192:251-53

Castle, R. O., Elliott, M. R., Wood, S. H. 1977. The southern California uplift EOS, Trans. Am. Geophys. Union 58:495 (Abstr.)

Clark, M. M., Grantz, A., Rubin, M. 1972. Holocene activity of the Coyote Creek fault as recorded in sediments of Lake Cahuilla, US Geol. Surv. Prof. Pap. 787: $112-20$

Coates, R. J., Clark, T. A., Counselman, C. C., Shapiro, I. I., Hinteregger, H. F., Rogers, A. E., Whitney, A. R. 1975. Very long baseline interferometry for centimeter accuracy geodectic measurements. Tectonophysics $29: 9-18$

Compton, R. R. 1977. Interpreting the Earth New York: Harcourt. 554 pp.

Cooper, W. S. 1923. The recent ecological history of Glacier Bay, Alaska. Ecology $4: 93-128,223-46,355-65$

Cooper, W.S. 1937. The problem of Glacier Bay, Alaska : A study of glacier variations. Geogr. Rev. 27:37-62

Cooper, W. S. 1939. A fourth expedition to Glacier Bay, Alaska. Ecology 20:130-59

Corte, A.E. 1969. Geocryology and engineering. In Reviews in Engineering Geology, ed. D. J. Varner, G. Kiersch, pp. 119-85. Geol. Soc. Am. 350 pp

Cotton, C. A. 1944. Volcanoes as Landscape Forms. Christchurch, New Zealand: Whitcombe \& Tombs. 416 pp.

Cutts, J. A. 1973. Wind erosion in Martian polar regions. J. Geophys. Res. 78:4211-21

Cutts, J. A., Smith, R. S. U. 1973. Eolian deposits and dunes on Mars. J. Geophys. Res. 78:4139-54

Davis, P., Smith, J., Kukla, G. J., Opdyke, N. D. 1977. Paleomagnetic study at a nuclear power plant site near Bakersfield, California. Quat. Res. 7:380-97

Dietz, R. S. 1961. Astroblemes. Sci. Am. 205: $50-58$

Dietz, R. S. 1963. Astroblemes-ancient meteorite-impact structures on the earth. In The Moon, Meteorites, and Comets, ed. B. M. Middlehurst, G. P. Kuiper, pp. 285-300. Chicago, Ill: Univ. Chicago Press. $810 \mathrm{pp}$.

Dietz, R. S. 1964. Sudbury structure as an astrobleme. J. Geol. 72:412-34

Eaton, J. P. 1959. A portable water-tube tiltmeter. Bull. Seismol.Soc. Am. 49: 301-16

Emmett, W. W. 1968. Gully erosion. In The Encyclopedia of Geomorphology, ed. 
R. W. Fairbridge, pp. 517-19. New York: Reinhold. 1295 pp.

Ewing, C. E., Mitchell, M. M. 1970. Introduction to Geodesy. New York: Elsevier. 304 pp.

Fanale, F. P. 1976. Martian volatiles: The degassing history and chemical fate. Icarus 28: 179-202

Frey, H. 1979. Martian canyons and African rifts : Structural comparisons and implications. Icarus $37: 142-55$

Gatto, L. W., Anderson, D. M. 1975. Alaskan thermokarst terrain and possible martian analog. Science $188: 255-57$

Geertsman, J. 1973. Land subsidence above compacting oil and gas reservoirs. $J$. Petrol. Tech. 25:734 44

Gifford, F. A. 1964. A study of martian yellow clouds that display movement. Mon. Weather Rev. 92:435-40

Gilbert, G. K. 1890. Lake Bonneville. US Geol. Surv. Monogr. 1. 438 pp.

Gilbert, G. K. 1928. Studies of Basin and Range Structure. US Geol. Surv. Prof. Pap. $153.92 \mathrm{pp}$.

Greeley, R. 1970. Observations of actively forming lava tubes and associated structures, Hawaii. Modern Geol. 2:207-23

Greeley, R. 1971a. Lunar Hadley Rille: Considerations of its origin. Science 172 : $722-25$

Greeley, R. 1971b. Lava tubes and channels in thelunar Marius Hills. Moon 3: 289-314

Greeley, R. 1973. Mariner 9 photographs of small volcanic structures on Mars. Geology $1: 175-80$

Greeley, R., ed. 1974. Geologic Guide to the Island of Hawaii. Office of Planetary Programs, NASA. 257 pp.

Greeley, R., Hyde, J. H. 1972. Lava tubes of the cave basalt, Mount St. Helens, Washington. Geol. Soc. Amer. Bull. 83: 2397-2418

Greeley, R., Iversen, J. D., Pollack, J. B., Udovich, N., White, B. R. 1974a. Wind tunnel studies of martian aeolian processes. Proc. R. Soc. London Ser. A 341 : $331-60$

Greeley, R., Iversen, J. D., Udovich, N., White, B. R. 1974b. Wind tunnel simulation of light and dark streaks on Mars. Science 183:847-49

Greeley, R., King, J. S., eds. 1977. Volcanism of the Eastern Snake River Plain, Idaho. Office of Planetary Programs, NASA. $308 \mathrm{pp}$.

Greeley, R., Womer, M. B., Papson, R. P., Sudis, P. D., eds. 1978. Aeolian features of Southern California. Office of Planetary Geology Programs, NASA. 264 pp.

Greene, G. W. 1966. Tiltmeter measurements. In Hunt, C. B., Maybe, D. R.,
1966. Stratigraphy and Structure, Death Valley, California, pp. 112-14. US Geol. Surv. Prof. Pap. 494-A. 162 pp.

Hartmann, W. K. 1974, Geological observations of martian arroyos. J. Geophys. Res. 79:3951-57

Heusser, C. J. 1954. Glacier fluctuations, forest succession, and climatic variations in the Canadian Rockies. Am. Philos. Soc. Yearb. 355-65

Heusser, C.J. 1956. Postglacial environments in the Canadian Rocky Mountains. Ecological Monogr. 26:263-302

Hobbs, W. H. 1917. The erosional and degradational processes of deserts with especial reference to the origin of desert depressions. Assoc. Am. Geogr. Ann. 7: 43-60

Hooke, R. LeB. 1972. Geomorphic evidence for Late Wisconsin and Holocene tectonic deformation, Death Valley, California. Geol. Soc. Am. Bull. 83:2073-98

Huggett, G. R., Slater, R. E. 1975. Precision electromagnetic distance-measuring instrument for determining secular strain and fault movement. Tectonophysics 29: 19-27

Huggett, G. R., Slater, R. E., Pavlis, G. 1976. Precision leveling with a two-fluid tiltmeter. Geophys. Res. Lett. 3:754-56

Huguenin, R. L. 1976. Mars: Chemical weathering as a massive volatile sink. Icarus 28:203-12

Hunt, C. B. 1966. Hydrologic Basin Death Valley, California. US Geol. Surv. Prof. Pap. 494 B. 138 pp.

Hunt, C. B., Maybe, D. R. 1966. Stratigraphy and Structure Death Valley, California. US Geol. Surv. Prof. Pap. 494 A. $162 \mathrm{pp}$.

Isachsen, Y. W. 1975. Possible evidence for contemporary doming of the Adirondack Mountains, New York, and suggested implications for regional tectonics and seismicity. Tectonophysics 29:169-81

Iversen, J. D., Pollack, J. B., Grceley, R., White, B. R. 1976. Saltation threshold on Mars: The effect of interparticle force, surface roughness, and low atmospheric density. Icarus $29: 381-93$

Izett, G. A., Wilcox, R. E., Powers, H. A., Desborough, G. A. 1970. The Bishop ash bed, a Pleistocene marker bed in the western United States. Quat. Res. 1:12132

Jennings, J. N. 1971. Karst. Cambridge, Mass.: MIT Press. $252 \mathrm{pp}$.

Johnson, N. M, 1975. Magnetic polarity stratigraphy of Pliocene-Pleistocene terrestrial deposits and vertebrate faunas, San Pedro Valley, Arizona. Geol. Soc. Am. Bull. 86:5-12 
Kaula, W. M., Chairman. 1978. Geodesy: Trends and Prospects. Washington, DC: Natl. Acad. Sci. 86 pp.

Keyes, C. R. 1912. Deflative scheme of the geographic cycle in an arid climate. Geol. Soc. Am. Bull. 23:537-62

Komar, P. D. 1979. Comparisons of the hydraulics of water flows in martian outflow channels with flows of similar scale on Earth. Icarus 37:156-81

Lachenbruch, A. H. 1962. Mechanics of Thermal Contraction Cracks and Ice Wedge Polygnns. Geol. Soc. Am. Spec. Pap. $70.69 \mathrm{pp}$.

Lamar, D. L., Merifield, P. M., Proctor, R. J. 1974. Earthquake recurrence intervals on major faults in southern California. In Geology, Seismicity and Environmental Impact, ed. D. E. Moran, J. E. Slosson, R. O. Stone, C. A. Yelverton, pp. 265-76. Los Angeles, Calif: Spec. Publ. Assoc. Eng. Geol, $444 \mathrm{pp}$.

Lamar, D. L., Muir, S. G., Merifield, P. M. 1979. Possible earthquake deformed sediments in Kern Lake, Kern County, California. Geol. Soc. Am. Abstr. Programs 11(3): 88 (Abstr.)

La Marche, V. C. 1968. Rates of slope degradation as determined from botanical evidence, White Mountains, California. US Geol. Surv. Prof. Pap. 3521 : 341-77

La Marche, V. C., Wallace, R. E. 1972. Evaluation of effects on trees of past movements on the San Andreas fault, northern California. Geol. Soc. Am. Bull. $83: 2665-76$

Lambert, R. St. J., Chamberlain, V. E. 1978. $\mathrm{CO}_{2}$ permafrost and martian topography. Icarus $34: 568-80$

Lawrence, D. B. 1950. Estimating dates of recent glacier advance and recession rates by studying tree growth layers. Trans. Am. Geophys. Union $31: 243-48$

Lawrence, D. B. 1958a. Historic landslides of the Gros Ventre Valley, Wyoming. Mazama 40: 10-20

Lawrence, D. B. 1958b. Glaciers and vegetation in southeastern Alaska. Am. Sci. $46: 89-122$

Leffingwell, E. deK. 1919. The Canning River Region, Northern Alaska. US Geol. Surv. Prof. Pap. 109.251 pp.

Leverett, F., Taylor, F. B. 1915. The Pleistocene of Indiana and Michigan and the History of the Great Lakes. US Geol. Surv. Monogr. 53.529 pp.

Loomis, A. A. 1965. Some geologic problems of Mars. Geol. Soc. Am. Bull. 76:10831104

Lucchitta, B. K. 1978. A large landslide on Mars. Geol. Soc. Am. Bull. $89: 1601-9$

Macdonald, G. A. 1972. Volcanoes, pp. 108-
121. Englewood Cliffs, NJ : Prentice-Hall. $510 \mathrm{pp}$.

Macdonald, G. A., Abbott, A. T. 1970. Volcanoes in the Sea. Honolulu: Univ. Hawaii Press. 441 pp.

Mackin, J. H. 1969. Origin of lunar Maria Geol. Soc. Am. Bull. 80:735-48

Maenaka, K., Yokoyama, T., Shiro, I. 1977. Paleomagnetic stratigraphy and biostratigraphy of the Plio-Pleistocene in the Kinki district, Japan. Quat. Res. 7: 341-62

Malde, H. E. 1968. The Catastrophic Late Pleistocene Bonneville Flood in the Snake River Plain, Idaho. US Geol. Surv. Prof. Pap. $596.52 \mathrm{pp}$.

Malin, M. C. 1974. Salt weathering on Mars. J. Geophys. Res. 74: 3888-94

Malin, M. C. 1977. Comparison of volcanic features of Elysium (Mars) and Tibesti (Earth). Geol. Soc. Am. Bull. 88:908-19

Malin, M. C. 1979. Mars: Evidence of indurated deposits of fine materials. 2nd Int. Colloq. Mars, NASA Conf. Publ. 2072, p. 54 (Abstr.)

Manabe, K.-I. 1977. Reversed magnetozone in late Pleistocene sediments from the Pacific Coast of Odaka, northeast, Japan. Quat. Res. 7: 372-79

Masursky, H., Boyce, J. M., Dial, A. L., Schaber, G. G., Strobell, M. E. 1977. Classification and time of formation of martian channels based on Viking data. J. Geophys. Res. 82:4016-38

Masursky, H., Crabill, N. L. 1976. Search for the Viking 2 landing site. Science 194: 62-68

Maxwell, T. A., Otto, E. P., Picard, M. D., Wilson, R. C. 1973. Meteorite impact: A suggestion for the origin of some stream channels on Mars. Geology 1:9-10

McCauley, J. F. 1973. Mariner 9 evidence for wind erosion in equatorial and mid-latitude regions of Mars. J. Geophys. Res. 78:4123-37

McCauley, J. F., Grolier, M. J., Breed, C. S. 1977. Yardangs of Peru and Other Desert Regions. US Geol. Surv. Interagency Rep. Astrogeology $81.177 \mathrm{pp}$. See also Geomorphology in Arid Regions, ed. D. O. Doehring, pp. 233-69. Binghamton, N.Y.: Publ. in Geomorphology. 272 pp.

McElroy, M. B. 1972. Mars: An evolving atmosphere. Science 175:443-45

McLaughlin, D. B. 1954a. Volcanism and eolian deposition on Mars. Geol. Soc. Am. Bull 65:715-17

McLaughlin, D. B. 1954b. Changes on Mars as evidence of wind deposition and volcanism. Astron. J. 60:261-70

McLaughlin, D. B. 1956. The volcanic-eolian hypothesis of Martian features. Publ. Astron. Soc. Pacific 68:211-18 
Meade, B. K. 1975. Geodectic surveys for monitoring crustal movements in the United States. Tectonophysics 29:103-12

Milton, D. J. 1973. Water and processes of degradation in the Martian landscape. J. Geophys. Res. 78:4037-47

Milton, D. J. 1974. Carbon dioxide hydrate and floods on Mars. Science 183:654-56

Mörner, N.-A. 1977. The Gothenburg magnetic excursion. Quat. Res. 7:413-27

Muller, S. W. 1947. Permafrost or Permanently Frozen Ground. Ann Arbor, Mich: Edwards Bros. $231 \mathrm{pp}$.

Mutch, T. A., Arvidson, R. E., Head, J. W., Jones, K. L., Saunders, R. S. 1976. The Geology of Mars. Princeton, NJ: Princeton Univ. Press. 400 pp.

Oakeshott, G. B., Greensfelder, R. W. 1972. 1872-1972, onc hundred years later. Calif. Geol. 25: 55-61

Opdyke, N. D., Lindsay, E. H., Johnson, N. M., Downs, T. 1977. The paleomagnetism and magnetic polarity stratigraphy of the mammal bearing section of Anza Borrego State Park, California. Quat. Res. 7:316-29

Page, R. 1970. Dating episodes of faulting from tree rings: Effects of the 1958 rupture of the Fairweather fault on tree growth. Geol. Soc. Am. Bull. 81:3085-94

Pavoni, N., Green, R., eds. 1975. Recent crustal movements. Tectonophysics $29: 1-$ 552

Pease, R. C. 1979. Fault scarp degradation in alluvium near Carson City, Nevada. Geol. Soc. Am. Abstr. Programs 11(3): 121

Péwé, T. L., ed. 1969. The Periglacial Environment: Past and Present. Montreal: McGill-Queens. 487 pp.

Piero, L. 1976. Volcanoes and Impact Craters on the Moon and Mars. New York: Elsevier. $432 \mathrm{pp}$.

Poland, J. F., Davis, G. H. 1969. Land subsidence due to withdrawal of fluids. In Reviews in Engineering Geology, ed. D. J. Varnes, G. Kiersch, pp. 187-269. 350 pp.

Porter, S. C. 1978. Glacier Peak tephra in the north Cascade Range, Washington: Stratigraphy, distribution, and relationship to late glacial events. Quat. Res. 10: $30-41$

Prescott, W. H., Savage, J. C. 1976. Strain accumulation on the San Andreas fault near Palmdale, California. J. Geophys. Res. 81:4901-8

Reilinger, R. E., Citron, G. P., Brown, L. D. 1977. Recent vertical crustal movements from precise leveling data in southwestern Montana, Western Yellowstone National Park, and the Snake River Plain. J. Geophys. Res. 82:5349-59

Rikitake, T. 1976. Earthquake Prediction.
Amsterdam: Elsevier. $357 \mathrm{pp}$.

Roddy, D. J., Peppin, R. O., Merrill, R. B., eds. 1978. Impact and Explosion Cratering: Planetary and Terrestrial Implications. New York: Pergamon. $1301 \mathrm{pp}$.

Ryan, J. A. 1964. Notes on martian yellow clouds. J. Geophys. Res. 69:3759-70

Sagan, C. 1973. Sandstorms and eolian erosion on Mars. J. Geophys. Res. 78: 4155-61

Sagan, C., Pollack, J. B. 1969. Windblown dust on Mars. Nature 223:791-94

Sagan, C., Veverka, J., Gierasch, P. 1971. Observational consequences of Martian wind regimes. Icarus 15:253-78

Savage, J. C., Prescott, W. H., Kinoshita, W. T. 1973. Geodimeter measurements along the San Andreas fault. In Proc. Conf. on Tectonic Problems of the San Andreas Fault System, ed. R. L. Kovach, A. Nur, pp. 44-53. Stanford Univ. Publ. Geol. Sci. 13. 494 pp.

Savage, J. C., Prescott, W. H., King, M. L. N. 1978. Strain in southern California: Measured uniaxial north-south regional compression. Science 202:883-85

Sharp, R. P. 1973a. Mars: Troughed terrain. J. Geophys. Res. 78:4063-72

Sharp, R. P. 1973b. Mars: Fretted and chaotic terrain. J. Geophys. Res. 78:407383

Sharp, R. P. 1973c. Mass movements on Mars. In Geology, Seismicity, and Environmental Impact, ed. D. E. Moran, J. E. Slosson, R. O. Stone, C. A. Yelverton, pp. 115-22. Dallas, Texas: Assoc. Eng. Geologists. 444 pp.

Sharp, R. P., Malin, M. C. 1975. Channels on Mars. Geol. Soc. Am. Bull. 86: 593-609

Shroder, J. F. 1978. Dendrochronological analysis of mass movements on Table Cliff Plateau, Utah. Quat. Res. 9:168-85

Sieh, K. E. 1978a. Prehistoric large earthquakes produced by slip on the San Andreas fault at Pallett Creek, California. J. Geophys. Res. 83:3907-39

Sieh, K. E. 1978b. Slip along the San Andreas fault associated with the great 1857 earthquake. Bull. Seismol. Soc. Am. $68: 1421-48$

Sigafoos, R. S. 1964. Botanical Evidence of Floods and Floodplain Deposition. US Geol. Surv. Prof. Pap. 485 A. 35 pp.

Sims, J. D. 1975. Determining earthquake recurrence intervals from deformational structures in young lacustrine sediments. Tectonophysics $29: 141-52$

Sirén, A. 1951. On computing the land uplift from the lake water level records in Finland. Fennia 73(5): 1-181

Slemmons, D. B. 1967. Pliocene and Quaternary crustal movements of the Basin- 
and-Range province, U.S.A. J. Geosci., Osaka City Univ. 10:91-103

Slemmons, D. B. 1969. New methods of studying regional seismicity and surface faulting. Trans. Am. Geophys. Union 50: 397-98

Slemmons, D. B. 1975 . Cenozoic deformation along the Sierra Nevada province and Basin and Range province boundary. Calif. Geol. 28:99-105

Slemmons, D. B., Carver, G. A., Cluff, L. S. 1969. Historic faulting in Owens Valley, California. Geol. Soc. Am. Spec. Pap. 121:559-60 (Abstr.)

Smith, D. G. W., Westgate, J. A. 1969. Electron probe technique for characterizing pyroclastic deposits. Earth Planet. Sci. Lett. 5: 313-19

Smith, H. W., Okazaki, R., Knowles, C. R. 1977a. Electron microprobe data for the tephra attributed to Glacier Peak, Washington. Quat. Res. 7: 197-206

Smith, H. W., Okazaki, R., Knowles, C. R. 1977b. Electron microprobe analysis of glass shards from tephra assigned to set W, Mount St. Helens, Washington. Quat. Res. 7:207-17

Smoluchowski, R. 1968. Mars: Retention of ice. Science 159:1348-50

Squyres, S. W. 1978. Martian fretted terrain: Flow of erosional debris. I carus $34: 600-13$

Stearns, R. S. 1966. Permafrost. US Army Material Command, Cold Regions Res. \& Eng. Lab. 77 pp.

Strom, R. G., Trask, N. J., Guest, J. E. 1975. Tectonism and volcanism on Mercury. J. Geophys. Res. $80: 2478-508$

Swinford, A. 1949. Source area of Great Plains Pleistocene volcanic ash. J. Geol. 57:307-11

Taber, S. 1943. Perennially frozen ground in Alaska, its origin and history. Geol. Soc. Am. Bull. 54:1433-548

Thatcher, W. 1976. Episodic strain accumulation in Southern California. Science 194: 691-95

Thatcher, W. 1979. Horizontal crustal deformation from historic geodectic measurements in southern California. $J$. Geophys. Res. 84:2351-70

Tolman, C. F. 1909. Erosion and deposition in the southern Arizona bolson region. J, Geol, 17:136-63

Tomlinson, R. W., Burger, T. C. 1977. Electronic Distance Measuring Instruments. Falls Church, Virginia : Am. Congr. Surv. Mapping. 79 pp. 3rd ed.

Trevena, A. S., Picard, M. D. 1978. Morphometric comparison of braided martian channels and some braided terrestrial features. I carus 35:385-94

Upham, W. 1884. Lake Agassiz: a chapter in glacial geology. Minnesota Geol. Surv. Ann. Rep. 11:137-53

Veverka, J. 1975. Variable features on Mars $\mathrm{V}$ : Evidence for crater streaks produced by wind erosion. Icarus 25:595-601

Veverka, J., Liang, T. 1975. An unusual landslide feature on Mars. I carus 24:47-50

Vitorello, I., van der Voo, R. 1977. Magnetic stratigraphy of Lake Michigan sediments obtained from cores of lacustrine clays. Quat. Res. 7: 398-412

Wade, F. A., deWys, J. N. 1968. Permafrost features in the Martian surface. Icarus $9: 175-85$

Wallace, R. E. 1968. Notes on stream channels offset by the San Andreas fault, southern Coast Ranges, California. In Geological Problems of the San Andreas Fault System, ed. W. R. Dickinson, A. Grantz. pp. 6-21. Stanford Univ. Publ. Geol. Sci. Ser. 11. $374 \mathrm{pp}$.

Wallace, R. E. 1969. Earthquake recurrence intervals on the San Andreas fault Cordilleran Sec. Geol. Soc. Am. Abstr. Programs 3: 71-72 (Abstr.)

Wallace, R. E. 1977. Profiles and ages of young fault scarps, north-central Nevada. Geol. Soc. Am. Bull. 88:1267-81

Wallace, R. E. 1979. Degradation of the Hegben Lake and Madison Range fault scarps, Montana. Geol. Soc. Am. Abstr. Programs 11(3): 133 (Abstr.)

Washburn, L. R. 1973. Periglacial Processes and Environments. New York: St. Martins Press. 320 pp.

Weber, G. E. 1979. Recurrence interval for surface faulting along the Frijoles fault and the Ano Nuevo thrust fault of the San Gregorio fault zone, San Mateo County, California. Geol. Soc. Am. Abstr. Programs 11(3): 134 (Abstr)

West, M. 1974. Martian volcanism: Additional observations and evidence for pyroclastic activity. Icarus $21: 1-11$

Whitcomb, J. H. 1976. New vertical geodesy. J. Geophys. Res. 81:4937-44

Whitten, C. A., Green, R., Meade, B. K. 1979. Recent crustal movements, 1977. Tectonophysics 52:1-663

Wilcox, R. E. 1965. Volcanic-ash chronology. In The Quaternary of the United States, ed. H. E. Wright, D. G. Frey, pp. 807-16. Princeton, NJ: Princeton Univ. Press. 922 pp.

Williams, H. 1932. The history and character of voleanic domes. Univ. Calif. Publ. Dept. Geol. Sci. Bull. 21:51-146

Wilson, M. E., Wood, S. H. 1980. Tectonic tilt rates derived from lake-level measurements, Salton Sea, California. Science 207: 183-86

Wilson, R. C., Harp, E. L., Picard, M. D., 
Ward, S. H. 1973. Chaotic terrain of Mars: A tectonic interpretation from Mariner 6 imagery. Geol. Soc. Amer. Bull. 84: 741-48

Wood, G. P., Wcaver, W. R., Henry, R. M. 1974. The Minimum Free-Stream Wind Speed for Initiating Motion of Surface Material on Mars. Tech. Mem. X-71959. NASA. 13 pp.

Wood, S. H., Elliott, M. R. 1979. Early
20th-Century uplift of the northern Peninsular Ranges province of southern California. Tectonophysics 52:249-65

Yung, Y. L., Pinto, J. P. 1978. Primitive atmosphere and implications for the formation of channels on Mars. Nature 273: $730-32$

Zoltai, S. C. 1975 . Tree ring record of soil movements on permafrost. Arct. Alp. Res. $7: 331-40$ 
Annual Review of Earth and Planetary Sciences

Volume 8, 1980

\section{CONTENTS}

Affairs OF THE SEA, Walter H. Munk 1

Platform Basins, Norman H. Sleep, Jeffrey A. Nunn, and Lei Chou 17

Geochemistry of Evaporitic Lacustrine Deposits, Hans P. Eugster 35

Cratering Mechanics--Observational, Experimental, and TheoretiCAL, H.J. Melosh

Heat Flow and Hydrothermal Circulation, C. R. B. Lister 95

Deformation of Mantle Rocks, Yves Gueguen and Adolphe Nicolas 119

Archean Sedimentation, Donald R. Lowe 145

The Dynamics of Sudden Stratospheric Warmings, James R. Holton 169

The Equatorial Undercurrent Revisited, S. G. H. Philander

Seismic Reflection Studies of Deep Crustal Structure, J. A. Brewer and J. E. Oliver

Geomorphological Processes on Terrestrial Planetary Surfaces, Robert $P$. Sharp

Geologic Pressure Determinations from Fluid Inclusion Studies, E. Roedder and R. J. Bodnar

Satellite Sensing of Ocean Surface Dynamics, John R. Apel

Quaternary DeEP-Sea Benthic Foraminifers AND BotTom Water MASSES, Detmar Schnitker

Rare Earth Elements in Petrogenetic Studies of Igneous Systems, Gilbert N. Hanson

Evolutionary Patterns in Early Cenozolc Mammals, Philip $D$. Gingerich

Origin and Evolution of Planetary Atmospheres, James B. Pollack and Yuk L. Yung

Fracture Mechanics APPlied to the Earth's Crust, John W. Rudnicki

Refractory Inclusions in the Allende Meteorite, Lawrence Grossman

\section{INDEXES}

AUTHOR INDEX

Cumulative Index of Contributing Authors, Volumes 4-8 